\title{
14
}

\section{Expanding the Role of Cooperative and Mutual Enterprises in Delivering Public Services: Disrupting the status quo}

\section{Melina Morrison and Cliff Mills}

\section{Introduction}

One could argue that many policy initiatives are based on a flawed (even arrogant) assumption-namely, that we can somehow work out how to change things by getting people and institutions to do things differently; where:

1. 'we' are those who consider that we have a duty, responsibility and right (government, important people in business, academia and civil society) to try to change things

2. 'working out how to change things' is based on a post-Enlightenment rationalist (we can), somewhat imperialist (we need to), but also modern nation-state (we must) way of thinking

3. 'getting people and institutions to do things differently' involves prescriptively making things happen to solve the problems that we have identified. 
A counter narrative might start like this: "Who do we think "we" are, and who are "they"?'

Should we reflect on whether we have the ability, the authority/ legitimacy and justification to intervene? And, might they have something to say, a part to play and possibly a different suggestion?

This is a brutal caricature of contemporary policymaking, but it fairly describes the experience of the mutual and cooperative sector in Australia.

\section{Explaining mutuality}

Mutuality has its origins in collective self-help: people doing things for themselves, their families and their communities because there is no one else to do it for them. Cooperatives were set up because there was a market failure in the availability of basic food and provisions (the private sector inflating goods prices, selling contaminated food and cheating on measures). Agricultural cooperatives were set up when farmers needed to collaborate to capture more value from the supply chain for the farm gate. Friendly societies and mutual insurance were established when there was no access to support in times of personal misfortune; and building societies were created when individuals aspired to provide for their own housing but could not do so (save by accident of birth) because there were no financial services available to them.

Because it is an alternative approach - alternative to private business, philanthropy and government - the whole dynamic, motivation, process, culture and governance of mutuality differs quite markedly from all of these. So, introducing the idea of mutuality and cooperation into this discussion about cross-sector working poses a challenge at the very least.

'Self-help' and mutuality occur because of something within each of us, which can emerge when we meet up with like-minded or similarly motivated people. Self-help emerges; you cannot do it to people.

This profound point has not been understood by many, including politicians, public servants and an army of professionals advisers who have been very busy doing something called 'mutualisation' to create 
'public sector mutuals'. This is true even in the United Kingdom, where the mutual sector has been on this journey for the past 15 years or more.

Those of us who spend our working lives in the cooperative and mutual sector view the possibility of some form of mutual ownership of public services with huge excitement. We devote our energies to this approach because we believe there is something transformative and 'right' about ordinary people owning and influencing their essential services, and about essential services being run for community or public benefit, rather than for the private benefit of investors.

We also know that in both the United Kingdom and Australia, the origins of public services - and of their ethos of providing for the vulnerable, the disadvantaged and the marginalised (universality, fairness and so on) - were not legal statutes, but communities and individuals. Before the state stepped in in the mid-twentieth century, there was already a rich tapestry of services provided by mutual (self-help) and philanthropic organisations, which individuals and communities were providing. The state took over because these services were too good and too valuable to be available just on a patchwork basis; states like ours wanted them to be universal.

So those of us from a mutual and cooperative background are excited to think that the ideas and principles that have survived in our current organisational types could become mainstream again. We also know that you cannot create mutuals from the top down, by government diktat or by simply commissioning private sector professionals who have no actual experience of mutuality to somehow convert existing public organisations into something different.

Indeed, there are many in the United Kingdom who believe that the so-called process of mutualisation or the creation of 'public service mutuals' has simply been a mask for privatisation, because the objective is to reduce the number of individuals on the state's payroll, and mutualisation is politically much more acceptable than privatisation (Gosling 2014). It could be argued that some of what the Community and Public Sector Union (CPSU) says about the UK experience in its submission to the recent inquiry into cooperative, mutual and member-based firms is broadly correct (Senate Standing Committees on Economics 2015). 
There is ideology and spin - on both sides - and this has led to some missed opportunities and mistakes. Some really good things have happened in the United Kingdom recently, but we do not want to make those 'mistakes' that have undermined the successes, and we have the knowledge and opportunity to make sure that we do not.

\section{Asking the right question}

If we are interested in mutual and cooperative ideas playing some part in the future of public services, we need to make sure we ask the right questions, before thinking about the answers.

The first question is not 'what legal structures could we use'. Legal structures do not create new types of organisations; people do. We need to address the question of what legal structure is used, but much later. First, we need to work out what we are aiming to do. Form follows function.

Nor should the question be: 'how do we turn our public services into public service mutuals?' Mutuality is not a magic wand or panacea. If income does not exceed expenditure, packaging a service up as mutual will not make it sustainable - nor will shoehorning a service into a mutual ownership structure somehow turn it into an actual mutual. Transactions processed by professionals do not create mutuals; people do.

If we want 'different' public services - where those using and those providing the services have a more engaged relationship and role in deciding how those services are provided and how they should evolve; where those services are economically sustainable with sound financial management, but where optimising the service for the benefit of the public is the fundamental purpose, not maximising profitability for investors - if we would like to see real change, not just the rearrangement of deckchairs, we need to realise that leaders and organisations like us do not make it happen. Ordinary people doby changing the way they behave.

If there are bold people who are willing to be pioneers in doing things differently, if workers and trade unions are willing to make common cause with users and citizens in communities and if there is appropriate leadership (Mills and Yeoman 2013) available to take 
these people with them, we might be able to help them solve some problems. We can share mutual ideas that have worked before and support them in developing the essentials of mutuality such as establishing a membership, building engagement and involvement and learning how to manage and govern differently. Perhaps we can sit alongside them as they develop their own scaffolding to support their new vision - an ownership and governance structure (the legal bits) which draws on what others have been doing, both two centuries ago and in this new millennium.

From the English experience (and it is English rather than UK; Scotland and Wales are on similar journeys, but via different routes), the first question is: What are the services where those involved in providing them want to deliver differently and want to work more closely with users and citizens?

And then: Can mutual and cooperative principles help to inform a new vision for the next stage of development of those services?

That might seem to be a strange place to start, but the reason is this: the ownership and governance models of public services are not the only things due for an update; rather, the way we plan and deliver those services needs to be re-examined, because it is no longer working as well as it could and, it is argued, it cannot continue to be funded on the current basis. Simply changing ownership and governance will not solve the problem. This, and the emergence of what is usually thought of as the 'public sector', needs to be explained further.

\section{The postwar settlement}

The publication of the Beveridge report in 1942 was a watershed moment for the United Kingdom and other states focused on the emerging role of what was to become the modern welfare state. It was in the postwar settlement based on Beveridge that the UK National Health Service (NHS) was born and a range of other services established as public services provided by the state and funded by central taxation. But public services, and their underlying ethos, were not created by statute. In short, the postwar settlement was the result of decades of development, thought and planning, because there was 
widespread recognition that the huge amount of existing services provided through self-help and philanthropy needed to be universally available, and the state was the best mechanism to achieve this.

In Australia, as observed by Alex McDermott in his history of Australian Unity (2015: 86), Robert Menzies freely conceded in his 1942 'forgotten people' radio broadcasts that after the war 'the functions of the State will be much more than merely keeping the ring within which the competitors will fight'. Our social and industrial obligations would be increased.

In the second half of the nineteenth century, Australians pioneered mutuals and friendly societies across the six colonies. Found in every community, these institutions were voluntary and self-regulating. By the eve of World War I, about 400,000 friendly society members helped to fund benefits for more than one million Australians (Andrews 2014). Self-help and philanthropy were the forerunners of the modern welfare state.

The problem today for many countries is that the state-based and tax-funded model has become economically unsustainable, due to demographic factors and spiralling demands on service provision at a time when many states are experiencing economic crises. But there is another fundamental cause of the current lack of sustainability and this is the whole approach to 'service delivery'.

Public services were born at a time when people did not live as long as they do today, when medical science was in its infancy and when people largely expected to have to provide for themselves. The decision by states to take on responsibility for providing a range of essential services to its citizens occurred at the end of World War II. Following a military campaign waged successfully through command and control and central coordination, the establishment adopted a similar organisational model to deliver public services to and for citizens.

Over the following decades, the introduction of performance management techniques from commercial manufacturing, of other market-based approaches, of new public management and of competitive tendering did not change the 'done-to' binary model of service delivery; however, it served to build a narrative that public servants and public services were (allegedly) inefficient, 
unaccountable and unimaginative, and it was used to drive arguments for privatisation and the commodification of services that are anything but commodities.

The United Kingdom now has examples of electronically tagged care workers tied to 15-minute time slots to 'deliver care' within a commercial framework seeking to maximise profits for investors.

Services that once were provided by and within communities have become something aimed at generating economic growth, rather than caring for people. Changing the ownership and governance structure of such commoditised services will not solve the issues. The whole approach to service delivery (now we have only binary language from the perspective of 'the provider') needs to be rethought, reimagined and redesigned to suit a different world.

We need a public health service not a public repair service, which is accessed only whenever our health is broken. We need to take responsibility as citizens for living healthier lives on the advice of health professionals, making better use of the money available for repairs. Service users and care professionals need to work together cooperatively to optimise health and well-being (Mills and Swarbrick 2014).

This is the starting point for modern mutual innovation: envisaging wholly new relationships as a context for more enlightened services, supported by a modern business and organisational model. There will be different approaches in different sectors and services, reflecting fundamental differences in the nature of those services, the context in which they are made available, the balance of relationships between those involved and many other key factors. But the common thread is always the people involved at the grassroots, how those people are connected to the service and how, by enabling different and new human relationships between those people, something more collaborative, more efficient and more focused on what is best for those people and their families and communities can emerge.

Crucially, those involved at the grassroots must include workers (and their unions). Their involvement and participation in developing a new vision is essential. Not only are workers also users themselves in another context; without appropriate terms and conditions and a fulfilling role that is fair to them as well as to citizens and users, 
any solution will be second best. Historically, there is much shared heritage between cooperatives and unions, and they need to make common cause again today in the public interest (Co-operative Heritage Trust 2016).

Working out a radically new approach requires a disruption to the historical way of seeing things, and a significant transfer of power. An example of such disruption is the National Disability Insurance Scheme - a big step towards giving users real power and choice. But will this alone disrupt the current marketplace of commoditised provision and turn it into something better? Will it help those trying to make a living as professional carers? Perhaps the concept of personalised budgets needs to go a step further. Individuals making individual choices can be relatively powerless; some do not necessarily find it helpful or advantageous, and some even find it stressful.

Individuals making choices collectively, however-collaborating for mutual support, maybe pooling budgets and seeking together to meet their own needs and the needs of others affected - is a transformative idea. A cooperative of personal budget holders, with a voice for family and friends, professional carers and local citizens? That would be disruptive.

This is the sort of new thinking needed to face today's challenges. A review of Australia's historical contribution to new thinking about the role of community, the role of the modern state and the role of individuals working collectively (please read McDermott 2015; it will inspire you) tells us that it is in our history, our heritage and our DNA to be pioneers and explore new thinking.

\section{The English experience}

Without wanting to be downbeat about what is going on elsewherebecause some of it is very good - here are some of the headline points from a review of what has been happening in England in relation to the mutualisation agenda. 


\section{Use of language}

The word 'mutual' has been devalued, many people have been confused and misled and the historical mutual and cooperative sector has had its reputation tarnished.

For example, the Cabinet Office (2015) says: 'Although the [mutual] sector has varying definitions, a public service mutual has three key characteristics: An organisation that has spun out of the public sector $\ldots$ and continues to deliver public services ... and involves a high degree of employee control.'

This reveals a limited understanding of mutuality. As you will see from our White Paper (BCCM 2014: 4), our definition is rather more demanding: 'an organisation which wholly or in part delivers public services through a co-operative or mutual governance structure, whereby members of the organisation are able to be involved in decision-making, and benefit from its activities, including benefits emanating from the reinvestment of surpluses.'

There has also been constant use in the United Kingdom of the phrase 'employer-owned/led mutuals' without a deeper understanding of the term and its inappropriateness.

Language is important. If it has the effect of misleading users, workers, communities and funders of services, disappointment will follow. Mutuals are based on trust and trusting personal relationships. Trust cannot be built up without clear and honest language - from the first conversation.

\section{'Mutualisation'}

As explained above, mutuality emerged from within communities as a self-help response to hardship. Communities, not consultants, public servants and governments, create mutuals.

The UK Cabinet Office approach has led to a number of professional firms with no experience or understanding of mutuality entering the business of 'creating' mutuals. Many have adapted the traditional consultancy and transactional approach used in privatisation (and in private sector sales and acquisitions) and then labelled the process 'mutualisation'. 
This creates the wrong impression of what is being established, and the short time scales involved based on electoral cycles and accounting years can make it very difficult to achieve something worthwhile from a mutual perspective, at times frustrating the sincere attempts by those involved to do something 'mutual'.

\section{The interesting stuff}

Some good and interesting things, however, are happening. There have been some pioneering individuals and organisations who have been captivated by what a mutual or cooperative approach could do for their services, and who have been passionate about creating the opportunity for their service users and employees to play a major role in re-establishing a bottom-up approach focused on what is best for those in need of services and those involved in providing them.

We have some great examples of such initiatives in Australia, including the consumer-owned medical practice business, National Health Co-operative, which was established in the Australian Capital Territory in 2010, and Co-operative Home Care, a non-residential, home care agency in Sydney that is owned by its employees, which was set up in 2012 (BCCM 2014).

What are the leading examples of this in the past few years in the United Kingdom and how have they been successful?

\section{How?}

Having said that mutuals cannot be created from the top down and that they emerge from communities, how can opportunities be captured, or even created, to enable new member-owned enterprises to emerge from public services?

\section{Leadership}

The first requirement is for visionary leadership within a service that instinctively or with some encouragement understands the possibilities. No previous experience of mutuality is needed, just an open mind, a willingness to learn and courage. 
A crucial element of that visionary leadership is a willingness to give away power. For many people and institutions, there is an instinct to hoard power and continue to seek to retain control even while expressly using the language of empowerment and localism. Within traditional mutual organisations, power starts from the membership, who, through some democratic and constitutional process, delegate most of that power to elected representatives and appointed executives. Changing to being member owned and controlled involves giving up a certain amount of power.

This is unlikely to happen without the existence of significant trust, which itself takes time and is based on personal relationships. Not only does the leadership need to have built up trust, it also needs to be willing to take risks based on that trust, to adopt a different leadership style and to take part in significant cultural change.

Unlike more traditional and hierarchical forms of management and governance, developing a user and worker-based sense of ownership requires a collaborative, collegiate approach to leadership, rather than the more traditional heroic 'alpha male' style. The grassroots membership is unlikely to put its efforts into making the whole venture more efficient and more successful and collectively 'taking ownership' unless it feels that it is sharing in something worthwhile, where its voice is heard and respected and where there is a sense of shared success.

\section{Type of service}

The second requirement is for an understanding of whether and, if so, how a cooperative approach to service delivery can substantially contribute to a better, more appropriate and relevant way of providing/ accessing that service. Mutuality is not a panacea or a magic wand, but it may have something significant to offer where the real engagement and participation of users, employees and citizens will transform a service from a binary, done-to approach to something much more dynamic and productive, to reduce costs or generate additional income or produce other substantial benefits and savings.

This may be the case where there is a significant involvement of unpaid support, volunteers or individuals giving their time and skills with no expectation of financial reward-for example, some types of care, 
working with young people, leisure services and so on. Whether their motivation for this is based on generosity of spirit, faith, a passion for something, lack of fulfilment elsewhere or simply boredom, where their organised contribution and engagement can make a difference to economic viability, some form of mutual ownership may provide a stabilising mechanism and an appropriate basis for such relationships.

\section{Funding and process}

In the United Kingdom, there are extensive European regulations governing the spending of public money and essentially requiring the promotion of competition. This can make it difficult if not impossible for a mutual approach to emerge. If a public body is required to put out to public tender a service it is currently providing in-house, it is virtually impossible for the in-house team to construct a credible bid that has any chance of defeating the highly professional and competitive skills of large external private sector bidders.

A mechanism is needed to enable those individuals and teams of people currently operating within public ownership to emerge as part of a mutually based initiative to operate outside state ownership. Such an initiative is very challenging, requiring its own cultural change for people who are not used to operating in a commercial and competitive environment and who have to become responsible for both earning income and controlling expenditure. It takes some time to acquire the skills to do this, and they therefore need a three to five-year start-up period in which to prepare for fully independent, commercial operation.

The well-established concept of splitting commissioning from provision can often be a hindrance to the emergence of new mutual services. The commissioner/provider split is a mechanism for using competition between potential contracting parties to drive the best bargain for the public purse. As already mentioned, this leads to the commodification of services by breaking them into parcels of work that businesses can price, but which bears no relationship to what is needed in many areas of public service - namely, a personal relationship.

This means it might be easier to explore the possibility of mutual and cooperative ideas where there is no commissioner or commissioning arrangements. In the United Kingdom, this has occurred successfully 
in the context of social housing, where the structure of state support is via housing benefits allocated to individuals. In Australia, the growing availability of personalised budgets may create opportunities, but, where commissioning is a legal requirement, some 'work-around' is needed to enable a mutual approach to emerge.

\section{Creating the environment}

It is worth adding that governments can do a number of things to make it more likely that cooperative and mutual ideas will be considered. Legislation is one possibility, but it should be approached cautiously. A good example of this is in Wales, where recent legislation in health and social care requires the promotion of cooperatives and social enterprise in the provision of care and support. ${ }^{1}$ This has been well received, but it remains to be seen if it is effective.

In England, legislation such as the Localism Act has created a series of rights, including the right to provide and the right to challenge. The Social Value Act has helped to raise awareness among public bodies, but more important from the point of view of cooperatives and mutuals is for the law establishing such organisations to be reviewed and modernised. This tends to happen every couple of decades for companies, but rarely if ever for mutuals.

Other positive legislative steps include things such as creating financial or fiscal advantages to encourage different types of businesses to emerge. Other legislative initiatives might focus on removing barriers or blockages. Sometimes statutory bodies can establish companies for certain purposes; this should be broadened to include mutual societies.

Most important is the removal of barriers to the emergence of self-help and cooperation, whether between individuals or corporate entities. Where competition law has the effect of inhibiting cooperation, this should be examined to check whether it is operating against the public interest.

A variety of other steps can be taken by governments to encourage the growth of mutuality, if they wish to do so (Mutuo 2010, 2015). The recommendations in the White Paper aim to promote, support

1 Available from: legislation.gov.uk/anaw/2014/4/pdfs/anaw_20140004_en.pdf (accessed 18 April 2016). 
and create an enabling environment for the establishment of 'public service mutuals' (BCCM 2014: 21-27); however, their establishment is not the objective. The objective is to make citizens and communities much more engaged in the way services are available to citizens and to support the emergence of something that is a sustainable and better option than state-based or marketised public services.

Direct action taken by government to 'create mutuals' can become another mechanism for delivering some other government objective. Only people in communities can create and 'own' mutual organisations; today's challenge is how, through education, inspiration, support and guidance, people can be stimulated to take such steps.

The financial crises since 2007 have probably been the biggest generator of cooperative and mutual initiatives in more developed economies in recent years, and this suggests we should focus more on how to support people who wish to pursue self-help solutions than on seeking to impose our preferred solution.

\section{What are the good examples in the United Kingdom?}

It is in social housing that some of the most significant progress has been made. This dates back more than 10 years to the development of a tenant member-based model for housing for the Welsh Assembly Government (the Community Housing Mutual). ${ }^{2}$ A number of housing providers have adopted this form in Wales (see, for example, Welsh Government 2014).

More recently and of greater interest has been the example of Rochdale Boroughwide Housing (RBH 2016), which developed a new tenant and employee-based model that went fully live in 2013 (see also Mutuo 2011b). A housing provider in South Wales is now adopting this approach and others are known to be interested in exploring it.

There have been significant developments in health care. A new member-based corporate model known as a 'public benefit corporation' (more popularly known as a foundation trust) was created by legislation

2 RCT Homes was the first to adopt this model, but not until 2007. See RCT Homes (2016). 
in 2003, and now more than half of NHS trusts (hospitals, mental health trusts and other specialist health providers) have adopted this format. It is a step in the direction of mutuality, but only partially because the state retains substantial powers in relation to the price at which foundation trusts sell their services and the mechanism for procuring services. Many see it as a step towards complete privatisation, but that has not happened yet.

In community health services, however, more significant steps have been taken, with the establishment of a number of care providers which are mainly employee owned and controlled, although actually set up as community interest companies or community benefit societies. These include Care Plus Group, Anglia Community Services and Medway Community Services (Mutuo 2011a).

There have been some interesting developments in other areas, including youth services (Knowsley Youth Mutual 2016; CCfC 2013), library services (Explore York 2014; Powell 2015) and leisure and culture (Salford Community Leisure Limited 2016).

At a national level, the approach begun by the previous (UK) Coalition Government in relation to the potential transfer of Post Office outof-state ownership to some kind of member-based model provides an illustration of an intelligent government-supported approach to the exploration of transition to mutual status by a national organisation (Co-operatives UK 2015).

\section{References}

Andrews, K. 2014. 'Foreword.' In Public service mutuals: A third way for delivering public services in Australia. White Paper, August, 3-4. Business Council of Co-operatives and Mutuals, Sydney.

Business Council of Co-operatives and Mutuals (BCCM). 2014. Public service mutuals: A third way for delivering public services in Australia. White Paper, August. Business Council of Co-operatives and Mutuals, Sydney.

Cabinet Office. 2015. Mutuals Support Programme. London: HMG. Available from: gov.uk/mutuals-support-programme (accessed 18 April 2016). 
Circle Crew for Change Limited (CCfC). 2013. Website. CCfC, Consett, UK. Available from: circlecrewforchange.com/ (accessed 18 April 2016).

Co-operative Heritage Trust. 2016. National Co-operative Archive. Manchester: Co-operative Heritage Trust. Available from: archive. coop/hive/common (accessed 18 April 2016).

Co-operatives UK. 2015. Mutual options for Post Office Ltd. Report to the Department for Business Innovation and Skills. Co-operatives UK, Manchester. Available from: uk.coop/resources/mutualoptions-post-office-ltd (accessed 18 April 2016).

Explore York. 2014. Explore York Libraries and Archives. York, UK: Explore York. Available from: exploreyork.org.uk/client/en_GB/ default (accessed 18 April 2016).

Gosling, P. 2014. 'When "mutualisation" of public services is actually privatisation.' Co-operative News, 26 August. Available from: thenews.coop/88845/news/general/when-mutualisation-of-publicservices-is-actually-privatisation/ (accessed 18 April 2016).

Knowsley Youth Mutual. 2016. Website. Knowsley Youth Mutual, Liverpool. Available from: youthmutual.co.uk/ (accessed 18 April 2016).

McDermott, A. 2015. Of No Personal Influence: How people of common enterprise unexpectedly shaped Australia. Melbourne: Australian Unity.

Mills, C. and G. Swarbrick. 2014. 'Going with the grain: Organising for a purpose.' London Journal of Primary Care (Abingdon) 6(1): 3-7. Available from: tandfonline.com/doi/abs/10.1080/17571472.2 014.11493404 (accessed 18 April 2016).

Mills, C. and R. Yeoman. 2013. 'The civic reinvention.' RSA Journal (3): 32. Available from: thersa.org/discover/publications-and-articles/ journals/issue-3-2013/ (accessed 18 April 2016).

Mutuo. 2010. The Mutuals Manifesto 2010. London: Mutuo. Available from: mutuo.co.uk/mutuals-manifesto-launched/ (accessed 18 April 2016). 
Mutuo. 201la. Community Health Services: Made mutual. London: Mutuo. Available from: mutuo.co.uk/wp-content/ uploads/201 1/10/Community-Health-Services-Made-Mutual1.pdf (accessed 18 April 2016).

Mutuo. 2011 b. Social Housing: Made mutual. London: Mutuo. Available from: mutuo.co.uk/wp-content/uploads/2011/10/Mutuals-socialhousing 1.pdf (accessed 18 April 2016).

Mutuo. 2015. The Mutuals Manifesto 2015: Business for people. London: Mutuo. Available from: mutuo.co.uk/news/business-forpeople-the-mutuals-manifesto-2015/ (accessed 18 April 2016).

Powell, J. 2015. 'Suffolk Libraries celebrates its 3rd birthday.' Suffolk Libraries Announcements, 31 July. Available from: suffolklibraries. co.uk/announcements/suffolk-libraries-celebrates-its-3rdbirthday (accessed 18 April 2016).

RCT Homes. 2016. More Than a Landlord. Mid Glamorgan, Wales: RCT Homes. Available from: rcthomes.co.uk/main. cfm?type=MORETHANALANDLORD\&object_id=2594 (accessed 18 April 2016).

Rochdale Boroughwide Housing Limited (RBH). 2016. Website. RBH, Manchester. Available from: rbh.org.uk/ (accessed 18 April 2016).

Salford Community Leisure Limited. 2016. Website. Salford, Manchester. Available from: salfordcommunityleisure.co.uk/ (accessed 18 April 2016).

Senate Standing Committees on Economics. 2015. CPSU (PSU Group) submission to the Inquiry into Cooperative, Mutual and MemberOwned Firms. July. Parliament House, Canberra.

Welsh Government. 2014. Allowing Fully Mutual Housing Associations to Grant Assured Tenancies. Cardiff: Welsh Government. Available from: chcymru.org.uk/en/about-us/useful-links/welsh-has-communitymutuals-and-other-members/ (accessed 18 April 2016). 
This text is taken from The Three Sector Solution: Delivering public policy in collaboration with not-for-profits and business, edited by John Butcher and David Gilchrist, published 2016 by ANU Press, The Australian National University, Canberra, Australia. 